\title{
DIE SAALKLERK AS HULPPERSONEELLID IN 'N AKADEMIESE HOSPITAALVERPLEGINGSEENHEID
}

\author{
T. van der Merwe en M. Muller
}

\begin{abstract}
Uittreksel
In 'n verkennende beskrywende studie is die verwagtinge (kennis en insig) van die eenheidsbestuurders sowel as saalklerke met betrekking tot die saalklerk se pligte en verantwoordelikhede in 'n verplegingseenheid van 'n akademiese hospitaal in Johannesburg bevraagteken en ondersoek. Die waarde van 'n gestruktureerde onderrigprogram vir saalklerke ter verbetering van hul vermoënsprofiel (kennis en insig) is ook bepaal. 'n Enkelgroep voor-en natoetsontwerp is gebruik om die verskil in insig en kennis (vermoënsprofiel) na die deurloping van 'n gestruktureerde onderigprogram te bepaal.
\end{abstract}

Die verwagtinge (kennis en insig) van eenheidsbestuurders van verplegingseenhede waarin saalklerke in die akademiese hospitaal wenksaam was, was swak ten opsigte van die saalklerk se pligte en verantwoordelikhede.

Die verwagtinge (kennis en insig) van saalklerke betreffende hul pligte en verantwoordelikhede in 'n verplegingseenheid van 'n akademiese hospitaal was ook swak. Hul vermoënsprofiel (kennis en insig) het egter statisties betekenisvol verbeter $(p=0,0000$ ) na deurloping van 'n gestruktureerde onderrigprogram in hierdie verband. Die verplegingseenheidsoriënteringsprogram het statisties geen betekenisvolle invloed op die resultate gehad nie behalwe ten opsigte van haar funksie as rolmodel en in die stel van waardes en norme.

Aanbevelings sluit in 'n gestruktureerde, toepaslike eerstevlak-bestuurskursus vir eenheidsbestuurders wat op dieselfde standaard as die verpleegbestuurskursusse aan universiteite is; 'n herstrikturering van die verplegingseenheidsoriënteringsprogram vir saalklerke, met gehyke insette van die eenheidsbestuurders en administratiewe beamptes; en laastens die benutting van die gestruktureerde onderrigprogram vir saalklerke in Transvaalse Provinsiale hospitale.

\section{Abstract}

The expectation (knowledge and insight) of unit managers as well as ward clerks regarding the duties and responsibilities of the ward clerk in an academic hospital nursing unit in Johannesburg were questioned. The value of a structured educational programme for ward clerks in order to improve their capabilities profile (knowledge and insight) was also examined.

The expectations (knowledge and insight) of unit managers in academic hospital nursing units where ward clerks were employed, were poor regarding the duties and responsibilities of such ward clerks.

The expectations (knowledge and insight) of ward clerks regarding their duties and responsibilities in an academic hospital nursing unit were also poor. However, their capabilities profile (knowledge and insight) showed a statistically significant improvement ( $p$ $=0,0000$ ) after completion of a structured educational programme an the subject. The nursing unit orientation programme had no significant influence on the results except for the ward clerk's function as a role model and in the setting of values and norms.

Recommendations include a structured, applicable, first level management course for unit managers which is of the same standard as nursing management courses at universities; restructuring of the nursing unit orientation programme for ward clerks, with equal inputs from the unit managers and administrative officers; and the use of the structured educational programme for ward clerks in Transvaal provincial hospitals.

\section{INLEIDING}

Voordat enige instelling, hetsy in die openbare of privaatsektor, 'n doelwit betekenisvol kan bereik, moet hy op drieërlei wyse toegerus wees: personeel, geld en 'n organisatoriese struktuur. Hoewel al drie die basiese insette tegelykertyd en in voldoende mate aanwesig moet wees om sukses te verseker, is die anwesigheid van personeel ongetwyfeld van die allergrootste belang. Ongeag die belangrikheid van geld en 'n behoorlike organisatoriese struktuur, is dit tog maar die personeel wat gaan bepaal of doelwitte bereik gaan word of nie. Hieruit kan dus afgelei word hoe belangrik personeelbestuur vir die bereiking van instellingsdoelwitte is (Andrews, 1985: Voorwoord).

Gedurende 1990 is daar deur die Adviserende Komitee vir Gesondheidsdienste (AKG 1990), tans bekend as die Komitee vir Gesondheidsaangeleenthede, verskeie ondersoeke van stapel 
gestuur na die dreigende krisis in die verpleegberoep, veral ten opsigte van professionele verpleegkundiges. Van die belangrikste redes wat vir ontevredenheid aangevoer word, is die swak salarisse en oneffektiewe personeelbestuur (Muller \& Coetsee, 1990). As daar gekyk word na hierdie faktore en die wanbenutting van die eenheidsbestuurder ten opsigte van nie-verpleegtake, is dit duidelik dat daar daadwerklik opgetree behoort te word om die taak van die eenheidsbestuurder pasiëntgesentreerd te hou.

Die tekort aan professionele verpleegkundiges noodsaak die optimale benutting van dié professionele verpleegkundiges en hulppersoneel wat vir eenheidsbestuurders in akademiese verplegingseenhede beskikbaar is, soos onder andere die saalklerk. Kotze (1990: 66) bevestig dat daar 'n duidelike afname in die groei van geregistreerde verpleegkundiges is. Die gemiddelde jaarlikse groei vir die tydperke 1949 tot 1959 en 1959 tot 1969 was naamlik 6,4\% en $6,8 \%$ onderskeidelik teenoor $4,0 \%$ en $3,1 \%$ onderskeidelik vir die tydperke 1969 tot 1979 en 1979 tot 1989. Die ontleding van die tendens sedert 1985 dui op 'n verontrustende verswakking in die situasie, naamlik 'n gemiddelde jaarlikse groei van 2,4\% vir 1985 tot 1989.

Die optimale benutting van menslike hulpbronne, geld, voorraad en metodes moet dus gesien word as effektiewe bestuur. Die verantwoordelikheid van die eenheidsbestuurder is doelbereiking deur effektiewe bestuur sodat al haar personeel optimaal benut kan word en produktief kan funksioneer in die daarstelling van gehalteverpleging.

Dit is dikwels net so moeilik om hulppersoneel te bekom as verpleegkundiges en hulle sal nie tot hospitaalwerk aangetrokke voel tensy daar 'n duidelike beroepstruktuur is nie. Ten einde die produktiwiteit van professionele verpleegkundiges te optimaliseer, is die effektiewe benutting en onderrig van die saalklerk van die grootste belang.

Van Tonder (1988: 6) bewys dat professionele verpleegkundiges $46,3 \%$ van hul tyd bestee aan nie-verpleegtake, waarvan $34,2 \%$ bloot klerklike take is. Die saalklerke in provinsiale hospitale word dus nie optimaal benut nie. Dit kan moontlik toegeskryf word aan die onjuiste verwagtinge by die saalklerk sowel as die eenheidsbestuurder ten opsigte van die pligte en verantwoordelikhede van die saalklerk in 'n hospitaakverplegingseenheid. Hierdie pligte en verantwoordelikhede sluit byvoorbeeld die volgende in: die bed tot bed kontrolering van alle pasiënte; alle administratiewe pligte met betrekking tot die opname van pasiënte, byvoorbeeld die opening van rekords; alle administratiewe pligte met betrekking tot die behandeling van pasiënte, byvoorbeeld die verkryging van ou rekords of bloeduitslae en die administratiewe pligte ten opsigte van oorplasings en ontslagte, byvoorbeeld familie in kennis stel of vervoerreëlings tref (Koch, 1986:209-212).

Die afwesigheid van 'n goedbeplande onderrigprogram vir saalklerke in 'n akademiese hospitaal beperk die ontwikkeling van die saalklerk se vermoëns en veroorsaak voorts 'n wanbenutting van hierdie hulppersoneellid.

Die volgende vrae is tersaaklik:

- Wat is die verwagtinge (kennis en insig) van die saalklerk ten opsigte van haar pligte en verantwoordelikhede in 'n akademiese hospitaalverplegingseenheid?

- Wat is die verwagtinge (kennis en insig) van die eenheids-bestuurder ten opsigte van die pligte en verantwoordelikhede van die saalklerk binne akademiese hospitaalverband?

- Waaruit behoort 'n onderrigprogram vir saalklerke in 'n hospitaalverplegingseenheid te bestaan?

- Is daar 'n verskil tussen die kennis en insig van die saalklerke met betrekking tot hul pligte en verantwoordelikhede voor- en nadat 'n onderrigprogram in hierdie verband deurloop is?

Die doelstellings met hierdie studie was die volgende:

a) die bepaling van die verwagtinge (kennis en insig) van die saalklerk, sowel as die eenheidsbestuurder betreffende die pligte en verantwoordelikhede van die saalklerk in 'n akademiese hospitaalverplegingseenheid;

b) die ontwerp, implementering en evaluering van 'n onderrigprogram vir saalklerke in 'n akademiese hospitaalverplegingseenheid;

c) die bepaling van die invloed van 'n onderrigprogram op die vermoënsprofiel (kennis en insig) van die saalklerk in 'n akademiese hospitaalverplegingseenheid.

\section{TERMINOLOGIE}

\section{Eenheidsbestuurder}

Die eenheidsbestuurder is 'n verpleegkundige wat 'n bevelpos in 'n provinsiale hospitaalverplegingseenheid beklee.

\section{Saalklerk}

'n Saalklerk is 'n hulppersoneellid wat in 'n verplegingseenheid aangestel is om sekere administratiewe funksies te verrig waarvoor verpleegvaardigheid nie nodig is nie.

\section{Onderrig}

Onderrig is 'n opleidingsaktiwiteit wat daarop gemik is om geselekteerde gedragsveranderinge by 'n individu teweeg te bring (Quinn, 1980: 8).

\section{Onderrigprogram}

'n Gestruktureerde program wat op wetenskaplike wyse ontwerp en geïmplementeer word om aan saalklerke hul pligte en verantwoordelikhede te verduidelik en hul insig en vermoënsprofiel in hierdie verband te verbeter.

\section{Vermoēnsprofiel}

'n Vermoënsprofiel is 'n metode om 'n persoon se sentrale aanleg (genadegawes) te bepaal. Dit toon 'n persoon se sterkpunte asook sy motiveringspatroon haarfyn aan (Rutter, 1985: 26).

\section{Verwagtinge en insig}

Verwagtinge is wat 'n persoon voorspel dat hy in 'n gegewe situasie sal kry (The Concise English Dictionary), asook sy vertroudheid met sy funksioneringsverantwoordelikhede (insig). In hierdie studie word verwagtinge en insig gegrond op die pligtelys van die saalklerk.

\section{Hospitaalverplegingseenheid}

'n Hospitaalverplegingseenheid is 'n afgebakende area in 'n akademiese hospitaal waar pasiënte verpleeg word en is sinoniem met "saal".

\section{Benutting}

Benutting is die aanwending van 'n persoon in 'n spesifieke pos.

\section{NAVORSINGSMETODOLOGIE}

'n Verkennende, beskrywende studie is binne kontekstuele verband gedoen om die verwagtinge van die saalklerk en eenheidsbestuurder met betrekking tot die pligte en verantwoordelikhede van die saalklerk as hulppersoneellid in 'n 
verplegingseenheid van 'n akademiese hospitaal te bepaal.

'n Enkelgroep- voor- en natoetsontwerp is vervolgens benut om te bepaal hoe 'n gestruktureerde onderrigprogram wat deur saalklerke in die navorsingshospitaal deurloop is, die vermoënsprofiel (kennis en insig) van die saalklerk beïnvloed het.

In hierdie studie was die teikenpopulasie saalklerke wat in verplegingseenhede van akademiese hospitale werk, asook die eenheidsbestuurders onder wie se toesig hierdie saalklerke gewerk het.

Al die persone wat 'n pos as saalklerk by die navorsingshospitaal beklee, was doelbewus by die navorsing betrek. Die aantal ulde poste by die navorsingshospitaal was 42 saalklerke, wat tussen Januarie 1991 en April 1991 by die hospitaal werksaam was, wat outomatiese doelgerigte seleksie tot gevolg gehad het. Sommige saalklerke was werksaam in twee verplegingseenhede.

Blokverdeling van die navorsingshospitaal het gestruktureerde onderhoudvoering vergemaklik. Twee saalklerke het verkies om nie aan die navorsing deel te neem nie.

Doelgerigte seleksie van eenheidsbestuurders is gedoen ooreenmstig die aantal poste deur saalklerke gevul. Al die eenheidsbestuurders $(N=47)$ wat 'n saalklerk in hul verplegingseenheid gehad het, is outomaties in die steekproef ingesluit.

Die eenheidsbestuurders was almal professionele verpleegkundiges in beheer van eenhede. Hierdie persone was almal tussen Januarie 1991 en April 1991 in eenhede werksaam waar saalklerke geplaas was.

Die navorsingstegniek het bestaan uit gestruktureerde onderhoudvoering met saalklerke sowel as eenheidsbestuurders. Hierdie navorsingstegniek is gebruik ten einde die verwagtinge (insig en kennis) van die saalklerk sowel as die eenheidsbestuurder ten opsigte van die funksie en verantwoordelikhede van die saalklerk te bepaal.

Die gestruktureerde vraelys wat tydens die onderhoud gebruik is, het ook die ontwerp van die vermoënsprofiel (insig en kennis) ingesluit. Dit het dus uit 'n voor- en natoets bestaan.

Vervolgens is 'n gestruktureerde onderrigprogram aangebied en 'n natoets by wyse van dieselfde vraelys afgeneem. Die onderrigprogram is ook deur middel van 'n gestruktureerde vraelys geëvalueer.

Die natoets is deur respondente as die klastoets afgelê. Dié klastoets (natoets) was 'n gestruktureerde vraelys wat as 'n toetsvraestel gebruik is.

Die siggeldigheid van die instrumente is deur vyf verpleegdiensbestuurders in die openbare en privaatsektor bevestig. Genoemde verpleegkundiges het meer as ses jaar ondervinding as verpleegdiensbestuurders en het saalklerke in hul verplegingseenhede in hul onderskeie hospitale.

Die statistiese betroubaarheid van die instrumente is, op aanbeveling van die statistiese konsultant, nie bepaal nie.

'n Gestruktureerde onderhoudkontrolelys is opgestel en gebruik om die betroubaarheid van die insigevaluerings te verhoog.

Die onderrigprogram is ook voorgelê aan die senior administratiewe beampte in beheer van die saalklerke, wat dit op haar beurt met haar vier administratiewe beamptes bespreek het. Siggeldigheid is ook deur hierdie persone bevestig.

Die onderrigprogram is in 'n klaskamersituasie aangebied.

$\mathrm{Na}$ afhandeling van die voortoets het die saalklerke in hanteerbare groepe van sestien, vyftien en nege 'n gestruktureerde onderrig-program deurloop. Die onderrigprogram het vyf dae geduur, van Maandag tot Vrydag, met 'n tydsduur van twee en 'n halwe uur per dag. Gedurende Maart 1991 en April 1991 is twee volle dae aan die laaste groep afgestaan en die natoets is twee dae later geskryf.

Die evaluering van die onderrigprogram het uit elf items bestaan en is in die vorm van stellings geformuleer waarvoor punte op 'n vyfpunt-Likertskaal toegeken is.

Hierdie program is aangebied na die funksionele bedrywighede van die saalklerke in die oggende. Weens die beperkte tyd wat aan hierdie onderrigprogram afgestaan kon word, het die navorser module III as 'n tuistaak gegee met 'n uitdeelstuk as bron. Module $\mathrm{V}$, naamlik "Organisasie en netheid by die stasie en lessenaar," is tesame met module VI as 'n tuistaak aan groepe gegee en deur saalklerke in die klas voorgedra.

Dit het begeleide selfstudie verbeter en groepsamewerking verhoog. Aan die einde van elke kursus is 'n klastoets van een en 'n halwe uur afgelê.

Die opleidingsprogram het uit ses modules bestaan. Die modules word hieronder kortliks beskryf.

Module een: Die inleiding tot die taak van die saalklerk. Hierdie module het ingesluit die geskiedenis van verplegingseenheidkoördinering, die vereistes wat aan die saalklerk gestel word, die etiese kode, 'n filosofie, en 'n klassifikasie van die saalklerk se pligte.

Module twee vervat die oriëntering ten opsigte van die hospitaalorganisasie. Hier word die stadia van siek-wees, die doelstelling en doelwitte van 'n hospitaal, die elemente van die verplegingseenheid, die organisatoriese struktuur en die pasiënt se siviele regte bespreek.

In module drie word die mediese terminologie, spesialiteite en afkortings behandel.

Module vier handel oor kommunikasie. Dit sluit in die elemente van kommunikasie, verantwoordelikhede, werkverhoudinge, praktiese stelsels en ontvangsdamepligte.

In module vyf word spesifieke funksies van die saalklerk bespreek. Hierdie funksies sluit in organisasie van die stasie, hospitaal-veiligheid, brandbestryding en -voorkoming, mediese noodgevalle, insidente en navorsing.

In module ses word die klerklike funksie behandel en dit sluit die volgende in: beleid- en eenheidslêers, verpleegpersoneelskedules, teater- en dieetlyste, opnames en ontslagte, toerusting en voor-rade, en pasiëntrekords en -verslae

\section{RESULTATE}

a) Die verwagtinge (kennis en insig) van die eenheidsbestuurder betreffende die pligte en verantwoordelikhede van die saalklerk in 'n akademiese hospitaalverplegingseenheid het die volgende resultate opgelewer Verdere inligting rakende ierdie resultate kan van die outeurs verkry word (vergelyk tabel 1).

Die meeste verplegeenheidsbestuurders, naamlik $70,2 \%(N=33)$, het drie jaar of minder ondervinding as eenheidsbestuurders gehad en $68,1 \%(\mathrm{~N}=32)$, het nie geweet of hul saalklerke 'n hospitaaloriënteringsprogram deurloop het en wat hierdie program behels het nie en $70,2 \%(N=33)$ van die respondente 
Tabol 1

Die gemlddelde insigtellings van die (eenheldbeatuurders) ten opsigte van calklerkpligte en -verantwoordellkhede op 'n Vyfpuntakaal. $(N=47)$

\begin{tabular}{|c|c|c|c|}
\hline Veranderllke & Gemiddelde & $\mathbf{S}$ & $\mathbf{N}$ \\
\hline Hospitaaloriëntasieprogram & 2,191 & 1,689 & 47 \\
\hline Verplegingseenheidorientasieprogram & 1,872 & 1,408 & 47 \\
\hline Inhoud van pligtestaat & 2,149 & 1,668 & 47 \\
\hline Offisiële pligtestaat & 2,362 & 1,699 & 47 \\
\hline Verduideliking & 3,468 & 1,544 & 47 \\
\hline Waardes/norme & 3,872 & 1,115 & 47 \\
\hline Tyd & 3,234 & 1,684 & 47 \\
\hline Inventaris & 1,723 & 1,297 & 47 \\
\hline Probleme & & & 47 \\
\hline * bestellings & 3,681 & 1,708 & 47 \\
\hline * afkeuring & 3,468 & 1,840 & 47 \\
\hline * diëte & 2,809 & 1,702 & 47 \\
\hline Organisatoriese kaart & 4,043 & 0,932 & 47 \\
\hline Saalkierk \& Org. kaart & 1,596 & 1,362 & 47 \\
\hline Skedulering & 2,021 & 1,437 & 47 \\
\hline Ontvangsdame & 3,894 & 1,108 & 47 \\
\hline Pasiëntnavrae & 4,043 & 1,250 & 47 \\
\hline
\end{tabular}

SLEUTEL:

S : Standaardatwyking

$N$ : Aantal respondente

het die oriëntering van die saalklerk nie as hul taak beskou nie.

Insig ten opsigte van die pligtelys van die saalklerk was swak en $68,1 \%(N=32)$ van die respondente het geen insig getoon nie.

Van die respondente, naamlik $87,2 \%$ (N $=41$, het verklaar dat 'n persoon se waardes en norme as baie belangrik ten opsigte van werkverrigting beskou kan word.

Baie van die respondente, naamlik $61,7 \%$ $(N=29)$, het gevind dat saalklerke probleme gehad het met die aanleer van prosedures.

Die meeste respondente, naamlik $74,5 \%$ $(\mathrm{N}=35)$, het die inventarisverantwoordelikhede as deel van die verplegingse enheidsbestuurder se funksie beskou en geen verantwoordelikheid aan die saalklerk afgestaan nie.

Die oorgrote meerderheid van die respondente, naamlik $72,4 \%(N=34)$, het probleme ondervind met die voorraadbestellings wat deur die saalklerk gedoen word en sommige van hierdie respondente het dit glad nie as die plig van die saalklerk beskou nie. Die instandhouding van voorrade en die vervanging en afkeuring van toerusting is egter 'n funksie van die saalklerk en word deur Van Tonder (1988: 11) as 'n nie-verpleegkundige taak beskou. Die aantal respondente wat hiermee probleme ondervind het, was $65,9 \%$ (N = 31).

Meer as die helfte van die respondente, naamlik $55,3 \%(\mathrm{~N}=26)$, het probleme gehad met die bestelling van diëte as 'n funksie van die saalklerk, terwyl $74,5 \%$ $(\mathrm{N}=35)$ goeie insig ten opsigte van die organisatoriese kaart getoon het. $87,2 \%$ $(\mathrm{N}=40)$, was nie bewus van die posisie van die saalklerk op die organisatoriese kaart nie. Dit geld haar inter- sowel as intradepartementele posisie.

Van die respondente, naamlik $76,6 \%$ (N $=36$ ), het die skeduleringsfunksie soos uiteengesit in die pligtelys nie as die plig van die saalklerk gesien nie. Koch (1986: 150 ) beveel in haar navorsing 'n pligtelys aan wat onder meer die oorskryf van verpleegpersoneelskedules insluit.

Die algemene insig met betrekking tot die funksie van die saalklerk as ontvangsdame was baie goed. Slegs $8,5 \%$ $(\mathrm{N}=4)$ van die respondente het die saalklerk nie as 'n ontvangsdame gesien nie.

Die hantering van pasiëntnavrae is deur $74,5 \%(\mathrm{~N}=35)$ van die respondente as die plig van die saalklerk gesien. Wanneer hierdie navrae nie meer hanteer kon word nie, moes dit na die eenheidsbestuurder verwys word.

Van al die respondente het net $4,3 \%$ (N $=2$ ) die hantering van die rollesing vir saalbediendes as die plig van die saalklerke gesien. Koch (1986: 150) beskou die rollesing vir bediendes as die plig van die saalkerk.

Meer as die helfte van die respondente, naamlik $53,2 \%(\mathrm{~N}=25)$, beskou rekordhouding nie as deel van die funksie van die saalklerk nie. Die saalklerk is verantwoordelik vir die hou van verslae en die instandhouding van pasiënt- en verpleegrekords (Rambo, 1978: 70 en Cox, 1984: 58).

Die meeste respondente, naamlik $38,3 \%$ $(\mathbf{N}=18)$, was ten gunste van 'n onderrigprogram van twee weke vir saalklerke. Van die ander respondente, naamlik $34 \%(\mathrm{~N}=16)$, het gevoel dat tydsduur nie vasgestel kon word nie.

Uit bogenoemde resultate kan die volgende gevolgtrekkings gemaak word:

- Die meeste verplegingseenheidsbestuurders het beperkte verplegingseenheidsbestuursondervinding gehad, te wete drie jaar of minder en beskou die saalklerk nie as deel van hul verantwoordelikheid in die eenheid nie, daarom het die eenheidsbestuurders ook geen leidinggewendefunksie ten opsigte van die saalklerk geopenbaar nie. Die leidinggewendefunksie van die eenheidsbestuurder behoort die oriëntering en onderrig van al die personeel in haar eenheid in te sluit.

- Insig betreffende die pligtelys/posbeskrywing van die saalklerk was swak omdat eenheidsbestuurders nie pligtelyste in die eenhede gehad het nie of hul eie onoffisiële pligtelyste saamgestel het. Van die eenheidsbestuurders was nie eers bewus dat daar 'n pligtelys vir die saalklerk bestaan nie. Die instandhouding van die inventaris, voorraadbestellings, die vervanging en afkeuring van toerusting, betrokkenheid by verpleegpersoneelskedules en rekordhouding was dus nie saalklerkfunksies nie.

- Eenheidsbestuurders was dit eens dat dit belangrik is om verwagtinge betreffende die pligtelys van die saalklerk uit te klaar.

- Saalklerke word nie as deel van die multidissiplinêre span beskou nie en eenheidsbestuurders sluit hulle dus nie in by verplegingseenheidaktiwiteite nie en daarom was sy ook nie ingesluit op die organisatoriese kaart nie.

- Eenheidsbestuurders wat ten gunste van 'n onderrigprogram was, het gevoel dat dit nie minder as twee weke 
Tabel 2

Student se t-toets: 'n vergelyking tussen dle voortoetstellings

on natoetstellings van (Saalkierke)

$$
(N=40)
$$

\begin{tabular}{|c|c|c|c|c|c|c|c|}
\hline Vraag & $\begin{array}{c}\text { Wearde } \\
\text { t-toots }\end{array}$ & \begin{tabular}{|c|} 
Gemiddelde \\
$\mathrm{X}$
\end{tabular} & $\mathbf{s}$ & $\begin{array}{l}5 \text { van VT } \\
\text { \&NT } \\
\end{array}$ & $\begin{array}{c}\text { Gemld. ven } \\
\text { verskllle }\end{array}$ & $\mathbf{N}$ & $\mathbf{P}$ \\
\hline Hulpverlening & $-4,10$ & $\begin{array}{l}\text { VT } 4,000 \\
\text { NT } 4,850\end{array}$ & $\begin{array}{l}1,340 \\
0,427\end{array}$ & 1,3117 & $-0,850$ & 40 & $0,0002^{4 *}$ \\
\hline $\begin{array}{l}\text { Doelstelling en } \\
\text { doelwitte }\end{array}$ & $-5,27$ & $\begin{array}{l}\text { VT } 2,775 \\
\text { NT } 4,100\end{array}$ & $\begin{array}{l}1,074 \\
1,277\end{array}$ & 1,5914 & $-1,3250$ & 40 & $0,0000^{*}$ \\
\hline Waardes en norme & $-3,93$ & $\begin{array}{l}\text { VT } 1,325 \\
\text { NT } 1,950\end{array}$ & $\begin{array}{l}0,694 \\
0,846\end{array}$ & 1,0048 & $-0,6250$ & 40 & $0,0003^{* * *}$ \\
\hline $\begin{array}{l}\text { Saalbeleid en } \\
\text {-prosedures }\end{array}$ & $-5,48$ & $\begin{array}{l}\text { VT } 1,275 \\
\text { NT } 2,450\end{array}$ & $\begin{array}{l}0,554 \\
1,358\end{array}$ & 1,3566 & $-1,1750$ & 40 & $0,0000^{\circ *}$ \\
\hline Stadia van siekwees & $-24,07$ & $\begin{array}{l}\text { VT } 1,075 \\
\text { NT } 4,700\end{array}$ & $\begin{array}{l}0,267 \\
0,939\end{array}$ & 0,9524 & $-3,6250$ & 40 & $0,0000^{* *}$ \\
\hline Pasiënt-regte & $-23,21$ & $\begin{array}{l}\text { VT } 1,825 \\
\text { NT } 4,750\end{array}$ & $\begin{array}{l}0,446 \\
0,630\end{array}$ & 0,7970 & $-2,9250$ & 40 & $0,0000^{\circ *}$ \\
\hline Gedragskode & $-14,36$ & $\begin{array}{l}\text { VT } 1,075 \\
\text { NT } 3,725\end{array}$ & $\begin{array}{l}0,267 \\
1,109\end{array}$ & 1,1668 & $-2,6500$ & 40 & $0,0000^{* *}$ \\
\hline Inventaris & $-3,75$ & $\begin{array}{l}\text { VT } 1,425 \\
\text { NT } 2,350\end{array}$ & $\begin{array}{l}0,984 \\
1,494\end{array}$ & 1,5589 & $-0,9250$ & 40 & $0,0006^{* *}$ \\
\hline Organisatoriese kaart & $-10,75$ & $\begin{array}{l}\text { VT } 1,075 \\
\text { NT } 3,975\end{array}$ & $\begin{array}{l}0,267 \\
1,656\end{array}$ & 1,7067 & $-2,9000$ & 40 & $0,0000^{*}$ \\
\hline Klassifikasie & $-9,52$ & $\begin{array}{l}\text { VT } 1,650 \\
\text { NT } 4,000\end{array}$ & $\begin{array}{l}0,622 \\
1,320\end{array}$ & 1,5616 & $-2,3500$ & 40 & $0,0000^{* *}$ \\
\hline Diens-skedules & $-4,61$ & $\begin{array}{l}\text { VT } 1,575 \\
\text { NT } 2,725\end{array}$ & $\begin{array}{l}1,083 \\
1,432\end{array}$ & 1,5779 & $-1,1500$ & 40 & $0,0000^{*}$ \\
\hline Oriëntering & $-3,43$ & $\begin{array}{l}\text { VT } 3,500 \\
\text { NT } 4,100\end{array}$ & $\begin{array}{l}0,847 \\
0,982\end{array}$ & 1,1048 & $-0,6000$ & 40 & $0,0014^{* *}$ \\
\hline Leierskap & $-6,55$ & $\begin{array}{l}\text { VT } 2,025 \\
\text { NT } 3,675\end{array}$ & $\begin{array}{l}0,920 \\
1,309\end{array}$ & 1,5941 & $-1,6500$ & 40 & $0,0000^{* \star n}$ \\
\hline Rolmodel & $-2,58$ & $\begin{array}{l}\text { VT } 3,475 \\
\text { NT } 4,100\end{array}$ & $\begin{array}{l}1,219 \\
0,955\end{array}$ & 1,5307 & $-0,6250$ & 40 & $0,0137^{*}$ \\
\hline $\begin{array}{l}\text { Leierskap } \\
\text { Motivering: }\end{array}$ & $-1,96$ & $\begin{array}{l}\text { VT } 3,500 \\
\text { NT } 3,950\end{array}$ & $\begin{array}{l}1,240 \\
1,108\end{array}$ & 1,4491 & $-0,4500$ & 40 & 0,0567 \\
\hline salaris & $-1,65$ & $\begin{array}{l}\text { VT } 4,000 \\
\text { NT } 4,400\end{array}$ & $\begin{array}{l}1,132 \\
1,128\end{array}$ & 1,5326 & $-0,4000$ & 40 & 0,1068 \\
\hline meriete & $-1,24$ & $\begin{array}{l}\text { VT } 4,200 \\
\text { NT } 4,525\end{array}$ & $\begin{array}{l}1,324 \\
1,037\end{array}$ & 1,6546 & $-0,3250$ & 40 & 0,2216 \\
\hline nuusbriof & 0,72 & $\begin{array}{l}\text { VT } 4,525 \\
\text { NT } 4,375\end{array}$ & $\begin{array}{l}0,905 \\
1,170\end{array}$ & 1,3117 & 0,1500 & 40 & 0,4738 \\
\hline bevordering & 0,68 & $\begin{array}{l}\text { VT } 4,775 \\
\text { NT } 4,650\end{array}$ & $\begin{array}{l}0,733 \\
0,975\end{array}$ & 1,1589 & 0,1250 & 40 & 0,4991 \\
\hline indiens opieiding & $-0,17$ & $\begin{array}{l}\text { VT } 4,800 \\
\text { NT } 4,775\end{array}$ & $\begin{array}{l}0,564 \\
0,733\end{array}$ & 0,9470 & 0,0250 & 40 & 0,8683 \\
\hline Konsepgroei & $-3,82$ & $\begin{array}{l}\text { VT } 3,950 \\
\text { NT } 4,650\end{array}$ & $\begin{array}{l}1,218 \\
0,770\end{array}$ & 1,1591 & $-0,7000$ & 40 & $0,0005^{\circ}$ \\
\hline Voortdurende groei & $-2,24$ & $\begin{array}{l}\text { VT } 3,775 \\
\text { NT } 4,175\end{array}$ & $\begin{array}{l}0,947 \\
1,152\end{array}$ & 1,1277 & $-0,4000$ & 40 & $0,0306^{*}$ \\
\hline Metodes van groei & $-4,93$ & $\begin{array}{l}\text { VT } 2,650 \\
\text { NT } 3,750\end{array}$ & $\begin{array}{l}1,210 \\
0,954\end{array}$ & 1,4106 & $-1,1000$ & 40 & $0,0000^{* *}$ \\
\hline Toesighouding & $-3,62$ & $\begin{array}{l}\text { VT } 2,875 \\
\text { NT } 3,575\end{array}$ & $\begin{array}{l}1,042 \\
0,958\end{array}$ & 1,2237 & $-0,7000$ & 40 & $0,0008^{* *}$ \\
\hline $\begin{array}{l}\text { VT : Voortoots } \\
\text { NT : Natoets } \\
\text { S : Standaardatwyking }\end{array}$ & \multicolumn{4}{|c|}{$\begin{array}{l}\mathrm{N} \text { : Aantal respondente } \\
\mathrm{P}: \text { Waarskynllkheid }\end{array}$} & \multicolumn{3}{|c|}{$\begin{array}{l}\text { : } 5 \% \text { peil van betekenis } \\
\text { : } 1 \% \text { pell van betekenis }\end{array}$} \\
\hline
\end{tabular}

moet duur nie, maar dat verskeie faktore in ag geneem moet word voordat 'n tydsduur bepaal kan word.

- Die hoë personeelomset was te wyte aan die swak salarisse, keuring en seleksie van saalklerke.

- Omdat personeelomset so hoog is en dit 'n "maandelikse instelling" geword
- Kommunikasie tussen die administratiewe beamptes en verplegingseenheidsbestuurders was volgens die eenheidsbestuurders swak. Dit het insidente soos die volgende ingesluit: eenheidsbestuurders is nie in kennis gestel van die verlof van die saalklerk nie; eenheidsbestuurders het gevoel dat hulle 'n beter persoonlike evaluering van die saalklerk se werkverrigting kon doen as die administratiewe beamptes.

Hieruit blyk dit dus dat die beroep nie kan bekostig om 'n skaars bron soos die professionele verpleegkundige oneffektief, naamlik vir nie-verpleegkundige take, aan te wend nie.

b) Die verwagtinge (kennis en insig) van die saalklerk betreffende haar pligte en verantwoordelikhede in 'n akademiese hospitaalverplegingseenheid, asook die verband tussen 'n gestruktureerde onderrigprogram en die vermoënsprofiel (kennis en insig) van die saalklerk, het die volgende resultate opgelewer (vergelyk tabel 2).

Hierdie vraelys is in vier afdelings verdeel, naamlik:

i) Afdeling A: Biografiese besonderhede.

ii) Afdeling B: Voortoets, en afdeling $C$ : Natoets.

iii) Onderrigprogram.

iv) Oriënteringsprogram.

\section{i) Biografiese besonderhede}

Al die respondente, naamlik $100 \%$ $(N=40)$, was in 'n akademiese hospitaal in Johannesburg werksaam. Die verplegingseenhede waarin hulle werksaam was, het gewissel. Die oorgrote meerderheid, naamlik $60 \%(N=24)$ van die saalklerke, het 'n matriekkwalifikasie gehad, met geen bykomende kwalifikasies in die groep nie. Aanstelling by die navorsingshospitaal het gewissel van 1958 tot April 1991. Van die totale aantal saalklerke was $65 \%(\mathrm{~N}=26)$ in die ouderdomsgroep 18-25 jaar en $15 \%(N=6)$ in die ouderdomsgroep 26-33 jaar. As daar na die ervaring van die saalklerke gekyk word, het die meeste, naamlik 45\% ( $\mathrm{N}=18$ ), minder as een jaar ervaring en is hulle onlangs aangestel. Daar was 27,5\% 
$(\mathrm{N}=11)$ saalklerke met een tot drie jaar ervaring. Met ander woorde, byna die helfte van die saalklerke is basies nog in die oriënteringsfase.

Slegs die helfte van die saalklerke, naamlik $50 \%(N=20)$, het 'n hospitaalori-nteringsprogram deurloop, en $22,5 \%(\mathbf{N}=9)$ van hulle het dit minder as twee jaar gelede deurloop. Wanneer die voortoetsresultate vergelyk word om die invloed van die verplegingseenheidsoriënteringsprogram te bepaal, blyk dit dat daar geen beduidende verband tussen bogenoemde program en resultate is nie.

Die verplegingseenheidsoriënteringsprogram is deur $70 \%(\mathrm{~N}=28)$ van die saalklerke deurloop.

Dit blyk asof saalklerke relatief jonk is en dat $60 \%(\mathrm{~N}=24)$ oor 'n matrikulasie-sertifikaat beskik.

\section{ii) Afdeling B en C: Voor- en natoets}

Die invloed van 'n onderrigprogram op die vermoënsprofiel (kennis en insig) van die saalklerk het die volgende resultate opgelewer (vergelyk tabel 2).

Die meeste saalklerke, naamlik $82,5 \%(\mathrm{~N}=33)$ in die voortoets en $97,5 \%(N=39)$ in die natoets, het beslis gevoel dat hulle die eenheidsbestuurder tot hulp is. Daar was dus ' $n$ beduidende verskil ( $p=$ 0,0002).

In die voortoets het die meeste respondente, naamlik $77,5 \%(\mathrm{~N}=$ 31 ), geen insig getoon ten opsigte van die rol wat hulle speel in die stel van waardes en norme in die eenheid nie. In die natoets het insig merkbaar verbeter. Meer as 'n kwart van die respondente, naamlik $27,5 \%(\mathbf{N}=$ $11)$, se insig het merkbaar verbeter. Daar was dus ' $n$ betekenisvolle verandering $(p=0,0000)$ wat ingetree het.

Insig ten opsigte van saalbeleid en -prosedures wat op die saalklerk se funksionering betrekking het, was swak in die voortoets. Die meeste respondente, naamlik $85 \%(N=34)$, het min of geen insig getoon. In die natoets het $65 \%(\mathrm{~N}=26)$ van die respondente 'n redelike tot baie goeie insig ten opsigte van hierdie plig en verantwoordelikheid getoon. Die verandering was dus betekenisvol $(p=0,0000)$.
Die respondente, naamlik $100 \%$ (N $=40$ ), kon in die voortoets glad nie die stadia van siekwees identifiseer nie, maar $90 \%(\mathrm{~N}=36)$ van die respondente het in die natoets uitstekende insig getoon. Die verandering was dus betekenisvol ( $p$ $=0,0000$ ).

Wat pasiëntregte betref, het $97,5 \%$ $(\mathrm{N}=39)$ van die respondente in die voortoets geen insig in die regte van pasiënte getoon nie. In die natoets het insig merkwaardig verbeter. Die aantal respondente wat goeie tot uitstekende insig getoon het, was $95 \%(\mathrm{~N}=38)$. Hier was ook 'n betekenisvolle verbetering ( $p=$ 0,0000).

Die respondente, naamlik $100 \%$ (N $=40$ ), het in die voortoets geen insig getoon ten opsigte van die gedragskode vir saalklerke nie. In die natoets het van die respondente, naamlik $52,5 \%(\mathrm{~N}=21)$, goeie insig in die gedragskode vir saalklerke getoon, wat 'n beduidende verskil (p $=0,0000$ ) was.

Die oorgrote meerderheid van die respondente, naamlik $90 \%(\mathrm{~N}=36)$, het swak tot gemiddelde insig in hul inventarispligte getoon. In die natoets was daar 'n merkbare verbetering, maar $50 \%(\mathrm{~N}=20)$ het die inventarispligte nog steeds nie as hul verantwoordelikheid beskou nie. Die verbetering was dus betekenisvolg. ( $p=0,0006)$.

Van die respondente, naamlik $92,5 \%$ $(\mathrm{N}=37)$, kon in die voortoets glad nie die saalklerkpligte klassifiseer nie. In die natoets het $62,5 \%(\mathrm{~N}=$ 25) van die respondente goeie insig getoon. Die verskuiwing was dus hier ook betekenisvol ( $p=0,0000)$.

Die gemiddelde insigtelling van respondente betreffende die rol wat hulle ten opsigte van diensskedulering van verpleegpersoneel vervul, was in die voortoets laag. Die meeste respondente, naamlik $75 \%(N=30)$, kon nie in die voortoets hul rol identifiseer nie. In die natoets was daar 'n merkbare verbetering ( $p=$ $0,0000)$ en $47,5 \%(N=19)$ van die respondente het goeie insig in hierdie rol getoon.

Die meeste respondente, naamlik $92,5 \%(\mathrm{~N}=37)$, het in die voortoets geen doel of waarde aan die organisatoriese kaart geheg nie. Hierdie insig het merkbaar verbeter in die natoets met die aantal respondente met goeie insig 72,5\% $(\mathrm{N}=29)$ wat 'n betekenisvolle ( $\mathrm{p}=$ $0,0000)$ verbetering was ( $p=$ 0,0000).

Van die respondente, naamlik $60 \%$ $(\mathrm{N}=24)$, het in die voortoets die belangrikheid van 'n oriënteringsprogram bevestig en $80 \%(\mathrm{~N}=32)$ van die respondente het in die natoets die belangrikheid van 'n oriënteringsprogram bevestig. Verbetering was dus ook betekenisvol $(\mathrm{p}=0,0014)$.

Goeie insig betreffende hul funksie as rolmodel is in die voortoets deur $55 \%(\mathrm{~N}=22)$ van die respondente getoon. In die natoets het die aantal respondente met goeie insig egter na $77,5 \%(N=31)$ verbeter, wat op 'n betekenisvolle verbetering dui ( $\mathrm{p}=$ 0,0137).

'n Aantal respondente, naamlik $65 \%$ $(\mathrm{N}=26)$, kon in die voortoets persone identifiseer teenoor wie hulle 'n leierskapsrol te vervul het. In die natoets was die aantal respondente groter, naamlik $80 \%$ (N $=32$ ). Die verbetering was egter nie beduidend nie ( $p=0,0567)$.

Daar was nie veel verskil ten opsigte van die motiveringsvlak van respondente in die voor-en die natoets nie. Salaris is as positiewe versterking ervaar deur $65 \%(\mathrm{~N}=$ 26) van die respondente in die voortoets en $87,5 \%(N=35)$ in die natoets. Meriete-erkenning is deur $77,5 \%(\mathrm{~N}=31)$ in die voortoets en $90 \%(\mathrm{~N}=36)$ in die natoets as positiewe versterking ervaar. Erkenning in die hospitaalnuusbrief is deur $85 \%(\mathrm{~N}=34)$ van die respondente in die voortoets en $82,5 \%(N=33)$ in die natoets as baie belangrik beskryf. Die meeste respondente, naamlik $95 \%(\mathrm{~N}=38)$ in die voortoets en $90 \%(\mathrm{~N}=36)$ in die natoets, het baie sterk gevoel oor bevordering as positiewe versterking.

In die voortoets het $97,5 \%(N=39)$ van die respondente gesê dat hulle indiensopleiding as 'n positiewe versterking ervaar, teenoor $95 \%(\mathrm{~N}$ $=38$ ) van die respondente in die natoets. Ten opsigte van al die genoemde veranderlikes was daar geen verbetering nie.

In die voor-sowel as die natoets het respondente die belangrikheid van voortdurende persoonlike groei erken. In die voortoets was daar $72,5 \%(N=29)$ en in die natoets 
$95 \%(N=38)$ wat dit eens was ten opsigte van hierdie aspek. Die verbetering was dus beduidend ( $p=$ 0,0005).

In die voortoets was dit vir respondente moeilik om metodes van groei te identifiseer. Slegs $20 \%$ $(\mathrm{N}=8)$ van die respondente kon metodes identifiseer, teenoor $\mathbf{5 7 , 5 \%}$ $(\mathrm{N}=23)$ van die respondente in die natoets. $\mathrm{Na}$ afloop van die onderrigprogram kon saalklerke dus metodes van "groei" identifiseer wat op'n merkbare verbetering gedui het $(p=0,0000)$.

In die voortoets het $52,5 \%(\mathrm{~N}=21)$ van die respondente gemiddelde insig ten opsigte van "toesighouding" getoon, terwyl $45 \%(\mathrm{~N}=18)$ in die natoets beter insig getoon het en kon sê wie hul toesighouers is en in watter opsigte toesighouding belangrik is. Verbetering was dus positief ( $p=$ 0,0008).

As daar gekyk word na die hoopvolheid en positiewe ingesteldheid van die respondente, kan hierdie saalklerke as positief en gemotiveerd bestempel word.

Die volgende gevolgtrekkings is met betrekking tot die saalklerk se funksionering gemaak:

- Die saalklerk beskou haarself as hulp vir die eenheidsbestuurder.

- Oriëntering van die saalklerke in die navorsingshospitaal het geen positiewe bydrae tot hul kennis en insig betreffende hul pligte en verantwoordelikhede tot gevolg gehad nie.

- Die beplanningsfunksie van die saalklerk word swak benut, te wete haar bydrae tot formulering van waardes en norme, haar funksionering met betrekking tot saalbeleid en -prosedures en haar inventarispligte.

- Haar organiseringsfunksie in die verplegingseenheid word ook swak benut, met die swak bydrae wat die saalklerk lewer ten opsigte van die diensskedules van die verpleegpersoneel, die gebrek aan 'n pligtelys en ook aan 'n organisatoriesekaart wat aandui waar die saalklerk inpas.

- Die beheerfunksie is vir saalklerke verwarrend. Hulle is nie bewus daarvan dat daar twee toesighouers, naamlik die eenheidsbestuurder en die administratiewe beampte, is nie. iii) Evaluering van die onderrigprogram

Al die respondente, naamlik $100 \%$ $(\mathrm{N}=40)$, het saamgestem dat die gehalte van die opleidingsprogram aan hul vereistes voldoen het en $97,5 \%(N=39)$, het saamgestem dat die opleiding praktyk-aangepas was.

Volgens $97,5 \%(N=39)$ van die respondente was die lesings duidelik en verstaanbaar en $92,5 \%(N=37)$, het die tempo van die lesings korrek gevind.

Die kennisvlak van die lesings is deur $97,5 \%(N=39)$ van die respondente as hoog ervaar en $97,5 \%(\mathrm{~N}=39)$, het gevind dat die dosent duidelik gepraat het.

Die organisasie en gestruktureerdheid van die lesings is deur almal, naamlik $100 \%(N=40)$ respondente, as hoog ervaar.

Die entoesiasme van die dosent oor die onderrigprogram is deur almal, naamlik $100 \%(\mathrm{~N}=40)$ as goed ervaar, terwyl $87,5 \%(\mathrm{~N}=35)$ dit as buitengewoon goed ervaar het en die meeste respondente, naamlik $97,5 \%$ $(\mathbf{N}=39)$, het verklaar dat hulle hierdie opleiding by hul kollegas sal aanbeveel.

Die gemiddelde persentasie wat aan hierdie kursus toegeken is, was $95,22 \%$.

Die Hotelling $\mathrm{T}^{2}$-toets vir die vektor van die gemiddelde van verskille tussen die voor- en natoetstellings van respondente toon 'n statisties betekenisvolle verskil

( $\mathbf{N}=0,0450)$ op 'n vyf persent peil van betekenis met 24 en 15,0 grade van vryheid. Dit dui dus daarop dat die onderrigprogram in die geheel suksesvol was.

iv) Verplegingseenheidsoriënteringsprogram ten opsigte van die insig van saalklerke (Voortoets)

Van die totale aantal saalklerke, naamlik $100 \%(N=40)$ was daar $70 \%(N=28)$ wat 'n verplegingseenheidsori-nteringspro gram deurloop het. Van hierdie $70 \%$ $(\mathrm{N}=28)$ het $30 \%(\mathrm{~N}=12)$ minder as een jaar gelede hierdie program deurloop.

Die verplegingseenheidsoriënteringsprogram het geen invloed op die insig van die saalklerk gehad nie.
Dit was duidelik dat die verplegingseenheidoriënteringsprogram nie die saalklerk met betrekking tot beter insig in haar pligte en verantwoordelikhede georiënteer het nie. Hierdie verplegingseenheidsoriënteringsprogram word dus bevraagteken wat betref die effektiwiteit daarvan.

Die resultate dui dus duidelik 'n leemte ten opsigte van die verplegingseenheidoriënteringsprogram aan. Van die eenheidsbestuurders, naamlik $70,2 \%$ $(\mathbf{N}=33)$, het die oriëntering van die saalklerk nie as deel van die eenheidsbestuurder se funksie ten opsigte van oriëntering gesien nie.

\section{AANBEVELINGS}

Op grond van bogenoemde gevolgtrekkings word die volgende aanbevelings gedoen:

- Daar word aanbeveel dat 'n eerstevlakbestuurskursus moet deurloop word om bestuursvaardighede te ontwikkel voordat persone as eenheidsbestuurders aangestel word, en dat so 'n kursus optimale benutting van die saalklerk as hulp-personeellid insluit.

- Optimale ontwikkeling van die saalklerk is van kardinale belang omdat groeitendense in die verplegingsmag jaarliks afneem en nie-verpleegtake besig is om die professionele verpleegkundige steeds van die pasiënt weg te hou.

- Aangesien die saalklerk as deel van die multidissiplinêre span funksioneer, moet sy ingesluit word by die formulering van 'n verplegingseenheidsfilosofie.

- Verskaf aan die saalklerk'n skriftelike kopie van die doelstellings en doelwitte vir haar pos asook haar/sy posverantwoordelikhede.

- Sluit die volgende in 'n geskrewe ori-nteringsprogram in:

- Die saalbeleid en - prosedures wat op haar funksionering betrekking het.

- Die identifisering van die stadia van siekwees.

-Die regte van 'n pasiënt tydens hospitalisasie.

- Die saalklerk se gedragskode.

- Gee aan saalklerke groter verantwoordelikheid ten opsigte van verple egpersoneelskedules (byvoorbeeld die oorskryf daarvan), die beantwoording van telefoniese 
navrae en die kommunikasie met die verpleegpersoneelkantoor in verband met byvoorbeeld verlof.

- Aandag moet gegee word aan die daarstelling van 'n organisatoriese kaart wat die posisie van die saalklerk in die verplegingseenheid aandui, asook haar verhouding tot die administratiewe beampte.

- Motivering moet versterk word deur middel van die verbetering van die basiese salaris. Dit is moeilik om aan hoërangordebehoeftes te dink as daar nie aan die basiese behoeftes voldoen is nie.

- Indiensopleiding moet op 'n gereelde basis, dit is minstens een maal per maand, plaasvind en saalklerke, eenheidsbestuurders en administratiewe personeel moet insette lewer.

- Gee aan saalklerke die verantwoordelikheid ten opsigte van die eenheid se inventaris.

- Doen verdere navorsing oor die implementering van vaardighede wat in die onderrigprogram aangeleer is.

Aanbevelings vir onderwerpe wat ingesluit moet word in die onderrigprogram, is die volgende: basiese noodhulp, rampbeplanning, kardiopulmonale resussitasie, aansteeklike siektes, siektetoestande in eenhede, meer onderrig oor kommunikasie en interpersoonlike verhoudinge.

Voorstelle ter verbetering van die kursus het die volgende ingesluit:

- Die betrokkenheid van administratiewe personeel by die aanbieding van die kursus.

- 'n Opvolgkursus vir saalklerke wat reeds hierdie kursus deurloop het.

- Meer tyd moet aan die kursus toegestaan word.

- Uitbreiding van kommunikasievaardighede deur spesifieke kursusse wat hierop fokus.

- Die kursus moet aangebied word voordat saalklerke in die eenheid geplaas word.

- Die betrokkenheid van verpleegpersoneel by die aanbieding van kursusse en dat kursusse Af in Engels Af in Afrikaans aangebied word.

Die verplegingseenheidsoriënteringsprogram moet in oorleg met die administratiewe personeel deur die eenheidsbestuurder hersien word.

\section{BEPERKINGS VAN DIE NAVORSING}

Aangesien die navorsing net 'n eenmalige studie by 'n enkele provinsiale hospitaal was, kan die bevindings hoogtens as verteenwoordigend van akademiese hospitale in die Transvaal en moontlik in die Republiek van Suid-Afrika beskou word.

Verdere beperkings was die volgende:

- die grootte van die steekproef. 'n Groter steekproef sou meer verteenwoordigend van saalklerke en eenheidsbestuurders gewees het;

- die tyd wat vir die onderrigprogram toegestaan is. Meer tyd sou groter diepte aan die program gegee het;

- subjektiwiteit (eensydigheid). Weens die onbeskikbaarheid van respondente is betroubaarheid van toetsresultate nie vasgestel nie. Dit was nie moontlik om die respondente weer uit die eenhede te onttrek nie;

- die invloed van die gestruktureerde onderrigprogram op die vermoënsprofiel (insig en kennis) van die saalklerk is by wyse van 'n enkelgroepontwerp bepaal. Die frekwensiegrootte bet nie 'n kontrolegroep moontlik gemaak nie.

Betroubaarheid van die natoets se resultate is weens praktiese probleme nie bepaal nie.

\section{SLOTOPMERKINGS}

Die eenheidsbestuurder is primêr verantwoordelik vir gehalteverpleging in haar eenheid. Gehalteverpleging word onderskryf deur effektiewe bestuur en effektiewe bestuur beteken die optimale benutting van personeel in die verplegingseenheid.

\section{ERKENNINGS}

Erkenning word hiermee gegee aan alle profesionele verpleegkundiges en saalklerke wat hierdie studie moontlik gemaak het.

Hierdie artikel is gebaseer op navorsing vir 'n M.Cur.-studie aan die Randse Afrikaanse Universiteit.

\section{BIBLIOGRAFIE}

ADVISERENDE KOMITEE VIR GESONDHEIDSAKE, (1990): Ondersoek na die verpleegberoep. Pretoria: Departement van Gesondheid.

ANDREWS, Y. 1985 : Die personeelfunksie. Pretoria: HAUM.

COX, R. (1984) : Being a health unit co-ordinator; second edition of being a ward clerk. Chicago: The hospital research \& educational trust.

KOCH, S. (1986): 'n Ondersoek na die opleiding van bykomende personeel in enkele geselekteerde Transvaalse provinsiale hospitale. Pretoria: Universiteit van Suid-Afrika (M.A.Cur.-verhandeling.)

KOTZE, W.J. (1990): Opweg na 2000: 'n uitdaging vir waagmoed en leierskap in die verplegingsberoep. Curationis, Desember 1990: 13 ( 3 \& 4) $65-75$.

MULLER, M.E. \& COETZEE, L. (1990): Verslag oor die ondersoek na die verpleegberoep. Pretoria. S.A.V.V.

QUINN, F.M. (1988) : The principles and practice of nurse education. Suffolk: St. Edmundsbury Press.

RAMBO, B.J. (1978) : Ward clerk skills. New York: McGraw-Hill.

RUTTER, G. (1985) : The "capabilities profile". Itemasionale personeelbestuurtydskrif, Februarie 1985: 3(10) 26 - 28.

VAN TONDER, S. (1988) : Nie-verpleginstake en die geregistreerde verpleegkundige. Curationis, 11(1), 6 - 11.

THELMA VAN DER MERWE

M.CUR Student, RAU

PROFEsSoR maAIE MULLER (co-author)

Department of Nursing Science, RAU 